\title{
Responses of Absorptive Root and Mycorrhizal Colonization of Chinese Fir (Cunninghamia Lanceolata) to Varied Environmental Conditions
}

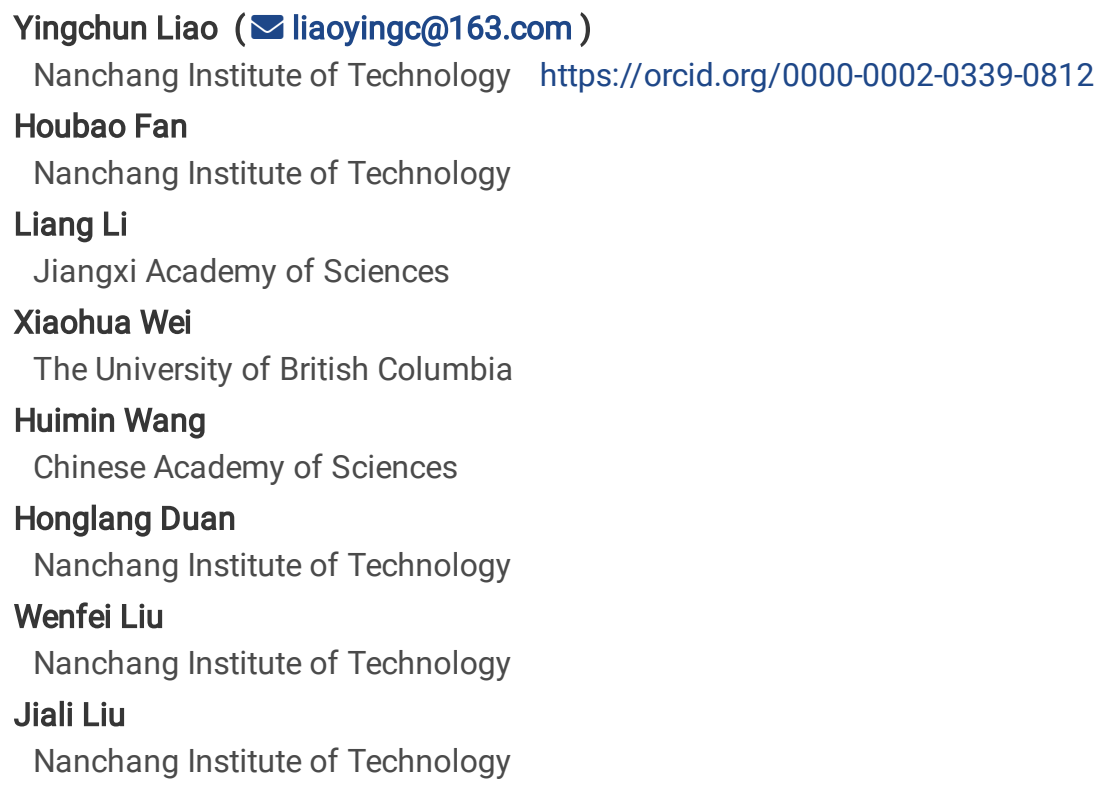

Research Article

Keywords: Absorptive roots , Branching ratio , Arbuscular mycorrhizal (AM) colonization , Chinese fir , Environmental conditions Posted Date: August 20th, 2021

DOI: https://doi.org/10.21203/rs.3.rs-707984/v1

License: (c) (1) This work is licensed under a Creative Commons Attribution 4.0 International License. Read Full License 


\section{Abstract}

Root branching and mycorrhizal symbioses are two major mechanisms for soil resources acquisition by trees. Understanding the relationship between these two mechanisms and their responses to varied environmental conditions are crucial for predicting the responses of foraging strategies of roots to environmental changes. This study was conducted in 11 Chinese fir (Cunninghamia lanceolata) plantations distributed in different environmental conditions in Subtropical China to assess the relationship between root tip traits related to nutrient foraging (branching ratio of 1 st order roots to 2 nd order roots and arbuscular mycorrhizal (AM) colonization) and their environmental variables including annual mean precipitation (MAP), annual mean temperature (MAT), soil C, soil N, soil P and soil $\mathrm{pH}$.

Results Root branching was more sensitive to environmental conditions than mycorrhizal symbioses. The branching ratio and AM colonization of Chinese fir were significantly related to several environmental variables. The branching ratios were positively correlated with MAT but negatively correlated with soil $\mathrm{C}$, soil $\mathrm{N}$ and soil $\mathrm{pH}(P<0.05)$, suggesting that harsh environmental conditions can promote absorptive root branching. To our surprise, the AM colonization of absorptive roots was not so sensitive to environmental factors as branching ratio. However, the AM colonization of absorptive roots was positively correlated with soil $\mathrm{pH}(P<0.1)$, indicating that soil acidity significantly controls mycorrhizal symbioses. Moreover, the branching ratio was significantly negatively correlated with AM colonization $(P<0.05)$. Our results confirmed that environmental conditions significantly regulate fine root branching and its mycorrhizal symbioses, but with different controlling variables. The negatively correlated relationship of branching ratio and AM colonization shows that environmental factors regulate absorptive root traits in different ways.

\section{Introduction}

Fine roots play key roles in soil resource acquisition (Johnson et al. 2003; Guo et al. 2008). They are plastic and their functional traits vary widely across plant species and environmental conditions (Guo et al. 2008; Holdaway et al. 2011). The morphology of fine roots is often directly related to physiological functions (Eissenstat 2000; Pregitzer et al. 2002) and the development of an efficient fine root system is crucial for trees to ensure sufficient nutrient uptake in various conditions (Ostonen et al. 2013).

Fine roots are composed of absorptive fine roots (usually referred to the first and second order roots) and transport fine roots (higher orders in the branching hierarchy), with the uptaking capacity of nutrients and water being declined with increasing root order (McCormack et al. 2015). Root tips (first order root) and their mycorrhizal symbioses (the association between the fungi and the roots) are the most metabolically active parts of absorptive fine roots. Their traits are good indicators of the adaptability of root systems to environmental conditions (Ostonen et al. 2017). The changes of root tip traits are expressions of the plastic responses to their environmental conditions (Ostonen et al. 2013; Kong et al. 2014a; Eissenstat et al. 2015; Soudzilovskaia et al. 2015).

Absorptive fine root traits such as diameter, surface area, branching ratio, specific root length (SRL), tissue density and mycorrhizal colonization are crucial for resource acquisition of trees (Eissenstat et al. 2015; Wang et al. 2016; Yan et al. 2019). However, recent studies showed that root traits can be divided into two major dimensions: 1) mycorrhizal colonization which is related to root construction, maintenance and persistence, and 2) branching architecture which is related to root plastic responses to environment (Kong et al. 2014b). Plants may choose to allocate resources to root tips or mycorrhizal fungi in different environmental conditions (Hodge and Storer 2015).

Plant root branching is a critical root trait (Liese et al. 2017) and is paramount for the acquisition of adequate soil water and nutrients (Duque et al. 2019). The plasticity of root systems in terms of the variations in the size, shape and surface area of the roots (Xie and Yu 2003; Motte and Beeckman 2019) was largely associated with root branching (Nibau et al. 2008). The capacity of root branching can improve the adaptation of plants to environmental conditions by anchoring and foraging in the soil (Motte and Beeckman, 2019). Usually, proliferating a predominance of absorptive roots was considered as an extensive fine root foraging strategy, which requires greater $\mathrm{C}$ allocation of trees to root formation (Ostonen et al. 2017). Contrary to prolific root branching, mycorrhizal colonization enhances the nutrient absorption of plants through the large surface area of mycelium (Smith and Read 2008), which was considered as an intensive fine root foraging strategy with less investment to fine roots (Ostonen et al. 2017). This inoculation of fungi of roots assists plants in obtaining nitrogen $(\mathrm{N})$, phosphorus $(\mathrm{P})$ and many other nutrients, as well as water from the soil (Clark and Zeto 2000; Jakobsen et al. 2005; Liese et al. 2017; Frew et al. 2018) to promote the growth of plants (Muthukumar and Udaiyan 2006; Kong et al. 2014b).

Due to significant influences to belowground and aboveground, fine root traits related to resource investment and acquisition-branching ratio and the rate of mycorrhizal colonization were considered as two important root traits in association with resources foraging 
strategies (Kong et al. 2014b; Zemunik et al. 2015; Liese et al. 2017; Chen et al. 2018). Thus it is important to understand the relationship between these two fine root traits and environmental conditions, which is essential to understand belowground resource acquisition of trees. In the past several decades, studies have found that branching architecture and mycorrhizal colonization showed large variations within species growing in different environmental conditions (Johnson et al. 2003; Loudet et al. 2005; Cudlin et al. 2007; Osmont et al. 2007). For example, plants allocate more biomass for root proliferation when growing together in interspecific plants competition (Hodge et al. 1999; Liao et al. 2019), which resulted in the increase of absorptive root (the first and second order roots) biomass (Guo et al. 2004; McCormack and Guo 2014).

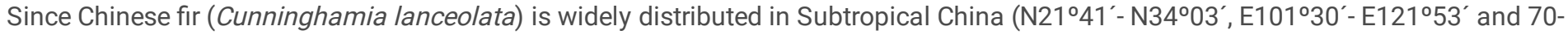
2900m in altitude) (Bian et al. 2014) and is the most important commercial plantation tree species in China, we chose Chinese fir as our study object. According to previous study (Piao and Liu, 2011; Li et al., 2019), Chinese fir is colonized with arbuscular mycorrhizal (AM) fungi and not colonized with ectomycorrhizas (EM). The main research objective of the study was to determine the relationship between these two mechanisms (root branching and root tip AM colonization) and environmental conditions (MAP, MAT, soil C, soil N, soil P, and soil pH) using Chinese fir plantation forests located in Subtropical China. We hypothesized that: 1) environmental variables were the main factors causing the variations of these two mechanisms, and 2) environmental conditions with limited resources (e.g. low soil $\mathrm{N}$ and soil P) resulted in the increase of AM colonization, as observed by Jakobsen et al. (2005) and Liu et al. (2015).

\section{Materials And Methods \\ Site description}

We collected the absorptive root samples in 11 Chinese fir plantations with the averaged age of 23 years located in different areas with different climates and edaphic conditions in Subtropical China from October to November of 2013, 2017 and 2018. The detailed information regarding the locations is presented in Table 1 and Table 2.

Table 1

The sampling locations and associated climate data

\begin{tabular}{|llllll|}
\hline Location & Longitude(E) & Latitude(N) & Altitude(m) & MAP* $(\mathrm{mm})$ & MAT* $\left({ }^{\circ} \mathrm{C}\right)$ \\
\hline Huitong & $110^{\circ} 08^{\prime}$ & $27^{\circ} 09^{\prime}$ & 500 & 1360 & 17.6 \\
\hline Shaxian & $117^{\circ} 43^{\prime}$ & $26^{\circ} 30^{\prime}$ & 200 & 1653 & 20.6 \\
\hline Taihe & $115^{\circ} 04^{\prime}$ & $26^{\circ} 44^{\prime}$ & 100 & 1453 & 19.4 \\
\hline Tongling & $117^{\circ} 59^{\prime}$ & $30^{\circ} 56^{\prime}$ & 430 & 1370 & 17.0 \\
\hline Pingxiang & $106^{\circ} 52^{\prime}$ & $22^{\circ} 03^{\prime}$ & 570 & 1275 & 23.2 \\
\hline Zhenxiong & $105^{\circ} 19^{\prime}$ & $27^{\circ} 60^{\prime}$ & 1243 & 1018 & 14.2 \\
\hline Zhengan & $107^{\circ} 53^{\prime}$ & $28^{\circ} 16^{\prime}$ & 970 & 1154 & 14.1 \\
\hline Yuexi & $116^{\circ} 23^{\prime}$ & $30^{\circ} 72^{\prime}$ & 275 & 1506 & 15.3 \\
\hline Shangcheng & $115^{\circ} 36^{\prime}$ & $31^{\circ} 43^{\prime}$ & 781 & 1376 & 13.4 \\
\hline Guangmingcun & $112^{\circ} 67^{\prime}$ & $27^{\circ} 21^{\prime}$ & 404 & 1564 & 16.4 \\
\hline Xinfeng & $115^{\circ} 18^{\prime}$ & $25^{\circ} 24^{\prime}$ & 278 & 1598 & 18.7 \\
\hline *MAT and MAP are given for $1961-2015$ in the locations (http://data.cma.cn/data/cdcdetail/dataCode/A.0029.0005.html) \\
\hline
\end{tabular}


Table 2

Stand characteristics of the 11 Chinese fir locations

\begin{tabular}{|c|c|c|c|c|c|c|c|c|c|c|}
\hline \multirow[t]{2}{*}{ Location } & \multirow{2}{*}{$\begin{array}{l}\text { Stand } \\
\text { age } \\
\text { (v) }\end{array}$} & \multirow{2}{*}{$\begin{array}{l}\text { Density } \\
\text { (trees } \\
\mathrm{ha}^{-1} \text { ) }\end{array}$} & \multirow[t]{2}{*}{$\mathrm{DBH}(\mathrm{cm})$} & \multirow{2}{*}{$\begin{array}{l}\text { AM } \\
\text { Colonization } \\
\text { (\%) }\end{array}$} & \multirow{2}{*}{$\begin{array}{l}\text { Branching } \\
\text { ratio }\end{array}$} & \multirow{2}{*}{$\begin{array}{l}\text { Root } \\
\text { diameter } \\
\text { of the } \\
1 \text { st order } \\
\text { roots } \\
(\mathrm{mm})\end{array}$} & \multicolumn{4}{|l|}{ Soil } \\
\hline & & & & & & & $\mathrm{pH}$ & $\begin{array}{l}\mathrm{C} \\
(\mathrm{mg} / \mathrm{g})\end{array}$ & $\begin{array}{l}\mathrm{N} \\
(\mathrm{mg} / \mathrm{g})\end{array}$ & $\begin{array}{l}\mathrm{P} \\
(\mathrm{mg} / \mathrm{kg})\end{array}$ \\
\hline Huitong & 23 & 1483 & 23.5 & 20.6 & 4.0 & 0.64 & 4.5 & 13.7 & 1.3 & 223.0 \\
\hline Shaxian & 21 & 1716 & 20.9 & 70.1 & 2.8 & 0.71 & 5.0 & 24.6 & 1.6 & 273.3 \\
\hline Taihe & 30 & 2245 & 15.5 & 53.5 & 3.6 & 0.53 & 4.7 & 7.0 & 0.9 & 109.8 \\
\hline Tongling & 20 & 950 & 16.1 & 57.1 & 2.6 & 0.66 & 4.8 & 19.4 & 1.9 & 464.3 \\
\hline Pingxiang & 20 & 1383 & 15.3 & 23.7 & 4.1 & 0.62 & 4.6 & 19.6 & 1.3 & 218.8 \\
\hline Zhenxiong & 17 & 2202 & 15.0 & 33.0 & 2.7 & 0.50 & 4.7 & 34.1 & 2.3 & 165.6 \\
\hline Zhengan & 16 & 2427 & 15.4 & 57.0 & 3.3 & 0.46 & 4.8 & 17.0 & 1.4 & 227.8 \\
\hline Yuexi & 23 & 1477 & 19.0 & 46.0 & 2.3 & 0.52 & 5.2 & 24.8 & 1.9 & 143.4 \\
\hline Shangcheng & 33 & 1041 & 28.3 & 47.0 & 2.2 & 0.51 & 5.1 & 55.2 & 4.0 & 249.0 \\
\hline Guangmingcun & 25 & 2084 & 15.2 & 57.0 & 3.1 & 0.49 & 4.8 & 24.1 & 1.7 & 114.0 \\
\hline Xinfeng & 21 & 1163 & 27.0 & 26.0 & 3.3 & 0.64 & 4.6 & 24.6 & 1.8 & 139.8 \\
\hline
\end{tabular}

\section{Root sampling}

In each location, we chose 9 Chinese fir individuals at random for root sampling. For each tree, six main lateral roots including the first five root orders were tracked by carefully removing surface soil $(0-20 \mathrm{~cm})$ at the base with a shovel and a fork. According to Pregitzer's study, the most terminal branch was defined as the first order roots (Pregitzer et al. 2002). The soil adhering to the roots was carefully removed and the intact roots were collected. Three of the lateral root samples were immediately placed into sealed polyethylene bags and placed on ice in a cooler and then transported to the laboratory and stored in a freezer at $-40^{\circ} \mathrm{C}$ to limit live tissue degradation (Clemensson-Lindell and Persson 1992) before root morphology measurements. Another three lateral root samples were immediately put into Formalin-Aceto-Alcohol (FAA) solution ( $90 \mathrm{ml}$ of $50 \%$ ethanol, $5 \mathrm{ml}$ of $100 \%$ glacial acetic acid, and $5 \mathrm{ml}$ of $37 \%$ formalin) for AM colonization assessments. The intact root branches for estimating branching ratios and AM colonization from each location were pooled as one composite sample separately (27 branches for estimating branching ratios and 27 branches for estimating AM colonization).

\section{Root branching ratio}

The frozen roots were then thawed, cleaned and immediately sorted. The root samples from each location were classified by root branch orders (with root tips as the first order roots) and the $1^{\text {st }}$ and $2^{\text {nd }}$ order roots were separated from the root samples. Root branching ratio was calculated as the number of the $1^{\text {st }}$ order roots divided by the number of the $2^{\text {nd }}$ order roots in this study.

\section{Root AM colonization}

Acid fuchsin staining (Giovannetti and Mosse 1980) was used to measure root AM colonization. After the root samples stored in FAA solution were washed with deionized water, the $1^{\text {st }}$ order root segments were selected and were cleared in hot $10 \%(\mathrm{w} / \mathrm{v}) \mathrm{KOH}$ solution at $90^{\circ} \mathrm{C}$ for $50 \mathrm{~min}$, acidified in $2 \% \mathrm{HCl}$ at room temperature for $5 \mathrm{~min}$ and stained with $0.05 \%$ (w/v) acid fuchsin at $90^{\circ} \mathrm{C}$ for 20 min (Liu et al. 2015). Then AM colonization of 501 -cm-long root segments was measured at $\times 200$ magnification (Leica DM 2500; Leica Mikrosysteme Vertrieb GmbH, Bensheim, Germany) using the line-intersect method described by McGonigle et al. (1990). Arbuscules, vesicles, non-septate and pink-colored hyphae within the roots were all considered as evidence of AM colonization, and overall colonization was calculated as the following formula:

AM colonization $(\%)=$ Number of AM segments scored/Total number of segments $\times 100 \%$ 


\section{Data analysis}

Root branching ratio and AM colonization were tested for normality using Shapiro-Wilk tests. Homogeneity of variance was checked using $\mathrm{F}$ tests. Linear regression was used to test possible relationships between root traits (Root branching ratio and AM colonization) and environmental conditions (MAP, MAT, soil $\mathrm{C}$, soil $\mathrm{N}$, soil $\mathrm{P}$, and soil $\mathrm{pH}, \mathrm{n}=11$ ). Statistical tests were considered significant at $P<0.05$. All analyses were carried out using SPSS 16.0 and SigmaPlot 12.5 statistical software.

\section{Results}

\section{The relationship between root branching ratio and environmental conditions}

The root branching ratios were varied from 2.1 to 4.0 across the 11 locations (Table 2). Root tips were sensitive to environmental conditions and were significantly affected by MAT, soil $\mathrm{C}$, soil $\mathrm{N}$, and soil pH. High temperature promoted more root tips as the branching ratios of Chinese fir were positively and significantly correlated to MAT $(P<0.05)$ (Fig. 1$)$. In contrast, root tips were significantly constrained by soil nutrients and soil pH as the branching ratios were negatively correlated with soil $\mathrm{C}$, soil $\mathrm{N}$ and soil pH $(P<0.05)(\mathrm{Fig}$. 1). In other words, poor nutrient conditions could promote more root tips or branching.

\section{The relationship between absorptive root AM colonization and environmental conditions}

The mean AM colonization of absorptive roots differed and varied from $23.7-70.1 \%$ across the 11 locations (Table 2). The regression analysis between the AM colonization and environmental variables showed that $\mathrm{AM}$ colonization of absorptive roots was not sensitive to climatic conditions (MAT, MAP) and soil nutrients (soil $\mathrm{C}$, soil $\mathrm{N}$, and soil $\mathrm{P})(P>0.05)$. But to our surprise, soil pH was positively correlated with the AM colonization of absorptive roots $(P<0.10)$ (Fig. 2), suggesting that soil $\mathrm{pH}$ might be an exclusive environmental factor regulating the AM colonization in our study region.

\section{Discussion}

Our results indicated that environmental variables are decisive in regulating absorptive root branching ratios and AM colonization in our studied forests. The branching ratios and AM colonization of the same tree species varied across locations with different environmental conditions. This was consistent with our first hypothesis that environmental variables were the main factors causing the variations of absorptive root branching ratios and AM colonization.

Our study showed that root tips are sensitive to climate and soil nutrients. The branching ratios were positively correlated with MAT but negatively correlated with soil $\mathrm{N}$ and soil pH (Fig. 1). The positive correlation of branching ratio and MAT proved that temperature was a significant climatic factor (Abbas Al-Ani and Hay 1983; McMichael and Quisenberry 1993) which could enhance the production of root tips (Nagel et al. 2009). The negative correlation of branching ratio with soil $N$ was consistent with the results from Zhang et al. (2007) and Chun et al. (2005) who showed that high $\mathrm{N}$ concentrations inhibited root tip meristem activity. The root branching ratios were also negatively correlated with soil pH and were high in the locations with low soil pH (e.g. Huitong and Pingxiang in Table 2; Fig. 1). The reason might be that the increase of soil acidity can result in the decline of soil microbial biomass $\mathrm{C}$, N, and nitrification (Kemmitt et al. 2006), which could lead to the deficiency of soil nitrogen availability, and consequently led to more root tips for increasing nutrient absorption. The relationships of branching ratios and environmental conditions suggested that more carbon resources were allocated to root tips to enhance the acquisition of soil water and nutrients under harsh environmental conditions (e.g., low soil nutrients and high soil acidity) (Duque and Lynch 2018).

In contrast, the absorptive root AM colonization of Chinese fir was not so sensitive to climatic conditions and soil nutrients (Fig. 1 and Fig. 2) in our study. The AM colonization did not show any significant relations with MAT, MAP, soil C, soil N, and soil P. The reason might be that our study locations are in Subtropical China with similar climate and soil properties. However, we found that mycorrhiza was significantly related to soil acidity, with the AM colonization being decreased with the decrease of soil pH significantly $(P<0.1)($ Fig. 2). This result is consistent with the results from previous studies that root AM fungi of plants was pH-sensitive (Kawahara et al. 2016; Rajasree et al. 2016) and was reduced but not eliminated in soils with low pH (Clark 1997; Frater et al. 2018). 
The relationship between root traits and environmental conditions in this study showed that soil acidity is an important environmental driver for the shifting of root foraging strategies of Chinese fir in Subtropical China. Both root tips and AM fungi were sensitive to soil pH in spite of their opposite directions (Fig. 3). The negative relationship of branching ratio and AM colonization in our study was consistent with the results from Price et al. (1989) and Hetrick et al. (1991) who showed that root branching could be reduced by AM fungal colonization, with the increasing mycorrhizal dependence for nutrients. Ostonen et al.'s (2017) study also showed that from temperate to boreal forests, the biomass of root tips increased, whereas the biomass of mycorrhizal decreased.

Our study showed that several other environmental factors such as MAT, soil C, soil N also played important roles in affecting root traits. The absorptive roots of Chinese fir chose to increase the branching of lower-order roots or AM colonization in different environmental conditions. Usually, either of these two traits dominates. But in harsh or stressed conditions, plants have evolved mechanisms that can compensate for lower nutrient availability (e.g. coldness and acid soils) and could depend on different strategies (Zadworny et al. 2016). For example, both the branching ratio and the AM colonization of absorptive roots were high in Taihe (Table 2). This might be related to high MAT, low soil nutrients (soil N and soil P) and high soil acidity in this area. To attain enough resources, the absorptive roots have to develop both root tips and mycorrhizal fungi.

\section{Conclusion}

Our study showed that absorptive root traits of Chinese fir had large variations spatially in responses to various environmental conditions. Soil nutrients (soil C and N) and climatic factor (MAT) were found to be important variables for fine root branching, but not for the AM colonization. Soil acidity was determined as an exclusive factor for regulating both the AM colonization and fine root branching. Those results provide important insights for predicting absorptive root traits in a future changing environment. Future more studies are needed to include more environmental gradients and cover more tree species to advance our understanding of the relationship between root nutrient foraging strategies and environmental conditions.

\section{Declarations}

\section{Acknowledgments}

This study was financially supported by the National Natural Science Foundation of China (31960308) and the Science and Technology Project of Jiangxi Education Department (GJJ201906).

\section{Author's contributions}

Liao YC, Wei XW and Wang HM conceived the ideas and designed methodology for the study; Liao YC and Li L collected data; Fan HB, Duan HL, Liu WF, and Liu JL led the writing of the manuscript. All authors contributed critically to the drafts and gave final approval for publication.

\section{References}

1. Abbas Al-Ani MK, Hay RKM (1983) The influence of growing temperature on the growth and morphology of cereal seedling root system. J Exp Bot 34:1720-1730

2. Bian L, Shi J, Zheng R, Chen J, Wu HX (2014) Genetic parameters and genotype-environment interactions of Chinese fir (Cunninghamia lanceolata) in Fujian Province. Can J Forest Res 44:582-592

3. Chen WL, Koide RT, Eissenstat DM (2018) Nutrient foraging by mycorrhizas: From species functional traits to ecosystem processes. Funct Ecol 32:858-869

4. Chun L, Mi G, Li J, Chen F, Zhang F (2005) Genetic analysis of maize root characteristics in response to low nitrogen stress. Plant Soil 276:369-382

5. Clark RB (1997) Arbuscular mycorrhizal adaptation, spore germination, root colonization, and host plant growth and mineral acquisition at low pH. Plant Soil 192:15-22

6. Clark RB, Zeto SK (2000) Mineral acquisition by arbuscular mycorrhizal plants. J Plant Nutr 23:867-902

7. Clemensson-Lindell A, Persson H (1992) Effects of freezing on rhizosphere and root nutrient content using two soil sampling methods. Plant Soil 139:39-45 
8. Cudlin P, Kieliszewska-Rokicka B, Rudawska M, Grebenc T, Alberton O, Lehto T, Bakker MR, Børja I, Konôpka B, Leske T, Kraigher H, Kuyper TW (2007) Fine roots and ectomycorrhizas as indicators of environmental change. Plant Biosyst 141:406-425

9. Duque L, Lynch J (2018) Genetic variability of root system architectural traits under phosphorus deficiency in sweet potato: interpreting efficiency, utilization and physiological performance. Proceedings of the 18th Triennial Symposium of the International Society for Tropical Root Crops; 2018 Oct 22-25, (Cali: CIAT Publication)

10. Duque LO, Villordon A (2019) Root branching and nutrient efficiency: Status and way forward in root and tuber crops. Front Plant Sci 10:237

11. Eissenstat DM (2000) Root Structure and Function in an Ecological Context. New Phytol 148:353-354

12. Eissenstat DM, Kucharski JM, Zadworny M, Adams TS, Koide RT (2015) Linking root traits to nutrient foraging in arbuscular mycorrhizal trees in a temperate forest. New Phytol 208:114-124

13. Frater PN, Borer ET, Fay PA, Jin V, Knaeble B, Seabloom E, Sullivan L, Wedin DA, Harpole WS (2018) Nutrients and environment influence arbuscular mycorrhizal colonization both independently and interactively in Schizachyrium scoparium. Plant Soil 425:493506

14. Frew A, Powell JR, Glauser G, Bennett AE, Johnson SN (2018) Mycorrhizal fungi enhance nutrient uptake but disarm defences in plant roots, promoting plant-parasitic nematode populations. Soil Biol Biochem 126:123-132

15. Giovannetti M, Mosse B (1980) An evaluation of techniques for measuring vesicular-arbuscular mycorrhizal infection in roots. New Phytol 84:489-500

16. Guo DL, Mitchell RJ, Hendricks JJ (2004) Fine root branch orders respond differentially to carbon source-sink manipulations in a longleaf pine forest. Oecologia 140:450-457

17. Guo DL, Xia MX, Wei X, Chang WJ, Liu Y, Wang ZQ (2008) Anatomical traits associated with absorption and mycorrhizal colonization are linked to root branching order in twenty-three Chinese temperate tree species. New Phytol 180:673-683

18. Hetrick BAD, Wilson GWT, Leslie JF (1991) Root architecture of warm-and cool-season grasses: Relationship to mycorrhizal dependence. Can J Bot 69:112-118

19. Hodge A, Robinson D, Griffiths BS, Fitter AH (1999) Why plants bother: root proliferation results in increased nitrogen capture from an organic patch when two grasses compete. Plant Cell Environ 22:811-820

20. Hodge A, Storer K (2015) Arbuscular mycorrhiza and nitrogen: Implications for individual plants through to ecosystems. Plant Soil $386: 1-19$

21. Holdaway RJ, Richardson SJ, Dickie IA, Peltzer DA, Coomes DA (2011) Species- and community-level patterns in fine root traits along a 120 000-year soil chronosequence in temperate rain forest. J Ecol 99:954-963

22. Jakobsen I, Chen B, Munkvold L, Lundsgaard T, Zhu Y (2005) Contrasting phosphate acquisition of mycorrhizal fungi with that of root hairs using the root hairless barley mutant. Plant Cell Environ 28:928-938

23. Johnson ND, Rowland L, Corkidi L, Egerton-Warburton LM, Allen EB (2003) Nitrogen enrichment alters mycorrhizal allocation at five mesic to semiarid grasslands. Ecology 84:1895-1908

24. Kawahara A, An GH, Miyakawa S, Sonoda J, Ezawa T (2016) Nestedness in arbuscular mycorrhizal fungal communities along soil $\mathrm{pH}$ gradients in early primary succession: acid-tolerant fungi are $\mathrm{pH}$ generalists. PLoS ONE 11:e0165035

25. Kemmitt SJ, Wright D, Goulding KWT, Jones DL (2006) pH regulation of carbon and nitrogen dynamics in two agricultural soils. Soil Biol Biochem 38:898-911

26. Kong DL, Ma CE (2014a) Acquisition of ephemeral module in roots: a new view and test. Sci Rep 4:5078

27. Kong DL, Ma CE, Zhang Q, Li L, Chen XY, Zeng H, Guo DD (2014b) Leading dimensions in absorptive root trait variation across 96 subtropical forest species. New Phytol 203:863-872

28. Li L, McCormack ML, Chen FS, Wang HM, Ma ZQ, Guo DL (2019) Different responses of absorptive roots and arbuscular mycorrhizal fungi to fertilization provide diverse nutrient acquisition strategies in Chinese fir. Forest Ecol Manag 433:64-72

29. Liao YC, Fan HB, Wei XH, Wu JP, Duan HL, Fu XL, Liu WF, Wang HM, Zhan XW, Tang P, Li F (2019) Competition increased fine root biomass in Chinese fir (Cunninghamia lanceolata) plantations in Subtropical China. Forest Ecol Manag 435:151-157

30. Liese R, Alings K, Meier IC (2017) Root branching is a leading root trait of the plant economics spectrum in temperate trees. Front Plant Sci 8:315

31. Liu BT, Li HB, Zhu B, Koide RT, Eissenstat DM, Guo DL (2015) Complementarity in nutrient foraging strategies of absorptive fine roots and arbuscular mycorrhizal fungi across 14 coexisting subtropical tree species. New Phytol 208:125-136

Page $7 / 11$ 
32. Loudet O, Gaudon V, Trubuil A, Daniel-Vedele F (2005) Quantitative trait loci controlling root growth and architecture in Arabidopsis thaliana confirmed by heterogeneous inbred family. Theor Appl Genet 110:742-753

33. McCormack ML, Guo DL (2014) Impacts of environmental factors on fine root lifespan. Front Plant Science 5:205

34. McCormack ML, Dickie IA, Eissenstat DM, Fahey TJ, Fernandez CW, Guo DL, Helmisaari H-S, Hobbie EA, Iversen CM, Jackson RB, Leppälammi-Kujansuu J, Norby RJ, Phillips RP, Pregitzer KS, Pritchard SG, Rewald B, Zadworny M (2015) Redefining fine roots improves understanding of belowground contributions to terrestrial biosphere processes. New Phytol 207:505-518

35. McGonigle TP, Miller MH, Evans DG, Fairchild GL, Swan JA (1990) A new method which gives an objective measure of colonization of roots by vesicular-arbuscular mycorrhizal fungi. New Phytol 115:495-501

36. McMichael BL, Quisenberry JE (1993) The impact of the soil environment on the growth of root systems. Environ Exp Bot 33:53-61

37. Motte H, Beeckman T (2019) The evolution of root branching: increasing the level of plasticity. J Exp Bot 70:785-793

38. Muthukumar T, Udaiyan K (2006) Growth of nursery-grown bamboo inoculated with arbuscular mycorrhizal fungi and plant growth promoting rhizobacteria in two tropical soil types with and without fertilizer application. New Forest 31:469-485

39. Nagel KA, Kastenholz B, Jahnke S, van Dusschoten D, Aach T, Mühlich M, Truhn D, Scharr H, Terjung S, Walter A, Schurr U (2009) Temperature responses of roots: impact on growth, root system architecture and implications for phenotyping. Funct Plant Biology 36:947-959

40. Nibau C, Gibbs DJ, Coates JC (2008) Branching out in new directions: the control of root architecture by lateral root formation. New Phytol 179:595-614

41. Osmont KS, Sibout R, Hardtke CS (2007) Hidden branches: developments in root system architecture. Annu Rev Plant Biol 58:93-113

42. Ostonen I, Rosenvald K, Helmisaari HS, Godbold D, Parts K, Uri V, Lõhmus K (2013) Morphological plasticity of ectomycorrhizal short roots in Betula sp and Picea abies forests across climate and forest succession gradients: its role in changing environments. Front Plant Sci 4:335

43. Ostonen I, Truu M, Helmisaari HS, Lukac M, Borken W, Vanguelova E, Godbold DL, Lõhmus K, Zang U, Tedersoo L, Preem JK, Rosenvald K, Aosaar J, Armolaitis K, Frey J, Kabral N, Kukumägi M, Leppälammi-Kujansuu J, Lindroos AJ, Merilä P, Napa Ü, Nöjd P, Parts K, Uri V, Varik M, Truu J (2017) Adaptive root foraging strategies along a boreal-temperate forest gradient. New Phytol 215:977-991

44. Piao HC, Liu CQ (2011) Variations in nitrogen, zinc, and sugar concentrations in Chinese fir seedlings grown on shrubland and plowed soils in response to arbuscular mycorrhizae-mediated process. Biol Fertil Soil 47:721-727

45. Pregitzer KS, DeForest JL, Burton AJ, Allen MF, Ruess RW, Hendrick RL (2002) Fine root architecture of nine North American trees. Ecol Monogr 72:293-309

46. Price NS, Roncadori RW, Hussey RS (1989) Cotton root-growth as influenced by phosphorus-nutrition and vesicular arbuscular mycorrhizas. New Phytol 111:61-66

47. Rajasree R, Harikumar VS (2016) Endomycorrhizal association in sesame. Effects on growth and nutrition. Anchor Academic Publishing, Hamburg

48. Smith SE, Read DJ (2008) Mycorrhizal symbiosis,3rd edn. Elsevier, London

49. Soudzilovskaia NA, Douma JC, Akhmetzhanova AA, van Bodegom PM, Cornwell WK, Moens EJ, Treseder KK, Tibbett M, Wang YP, Cornelissen JHC (2015) Global patterns of plant root colonization intensity by mycorrhizal fungi explained by climate and soil chemistry. Global Ecol Biogeogr 24:371-382

50. Wang P, Diao FW, Yin LM, Huo CF (2016) Absorptive roots trait plasticity explains the variation of root foraging strategies in Cunninghamia lanceolata. Environ Exp Bot 129:127-135

51. Xie Y, Yu D (2003) The significance of lateral roots in phosphorus (P) acquisition of water hyacinth (Eichhornia crassipes). Aquat Bot 75:311-321

52. Yan GY, Zhou MX, Wang M, Han SJ, Liu GC, Zhang X, Sun WJ, Huang BB, Wang HL, Xing YJ, Wang QG (2019) Nitrogen deposition and decreased precipitation altered nutrient foraging strategies of three temperate trees by affecting root and mycorrhizal traits. Catena 181:104094

53. Zadworny M, McCormack ML, Mucha J, Reich PB, Oleksyn J (2016) Scots pine fine roots adjust along a 2000-km latitudinal climatic gradient. New Phytol 212:389-399

54. Zemunik G, Turner BL, Lambers H, Laliberté E (2015) Diversity of plant nutrient-acquisition strategies increases during long-term ecosystem development. Nat Plants 1:1-4 
55. Zhang H, Rong H, Pilbeam D (2007) Signalling mechanisms underlying the morphological responses of the root system to nitrogen in Arabidopsis thaliana. J Exp Bot 58:2329-2338

Figures
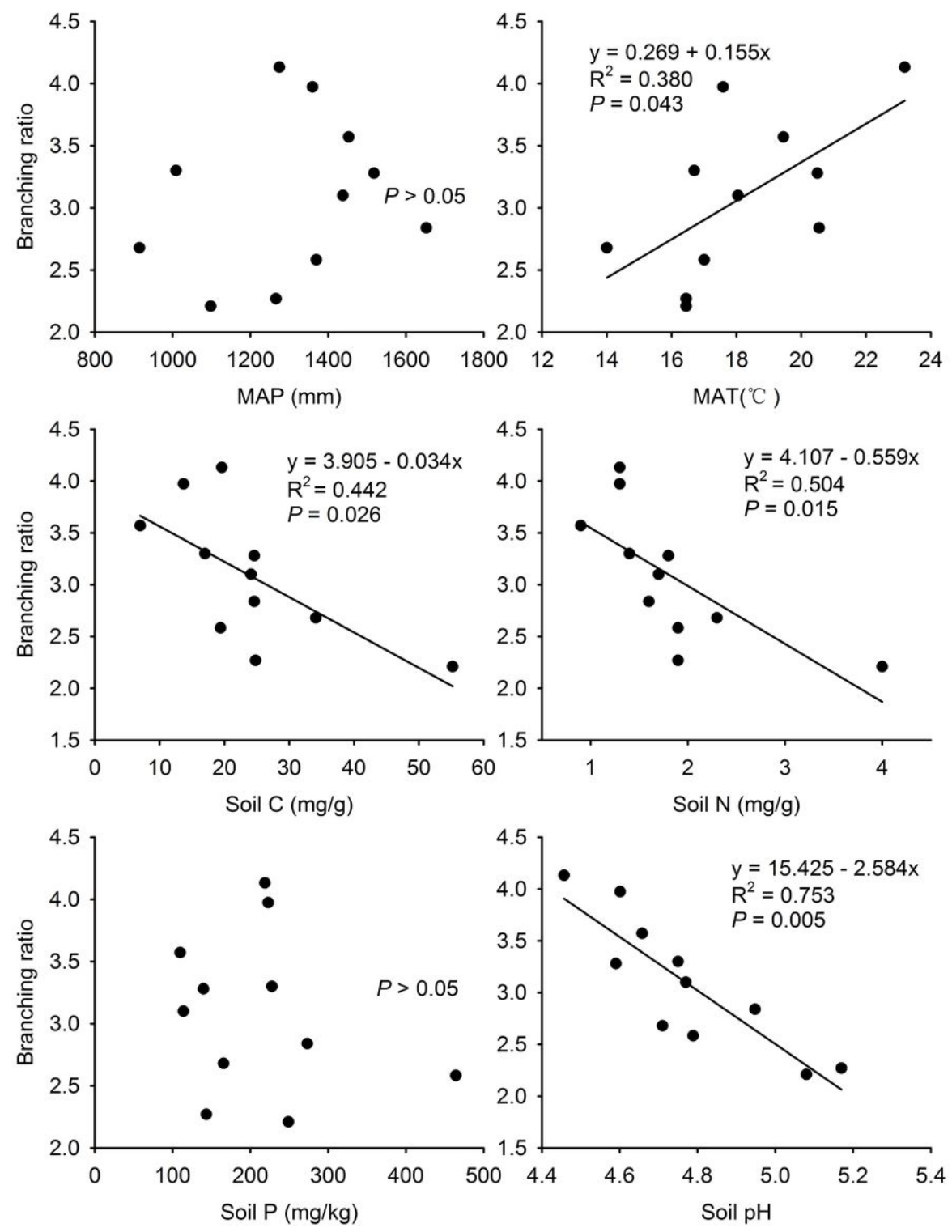

\section{Figure 1}

Linear regressions of branching ratio and environmental factors $(\mathrm{N}=11)$ (values are means of individual locations). 

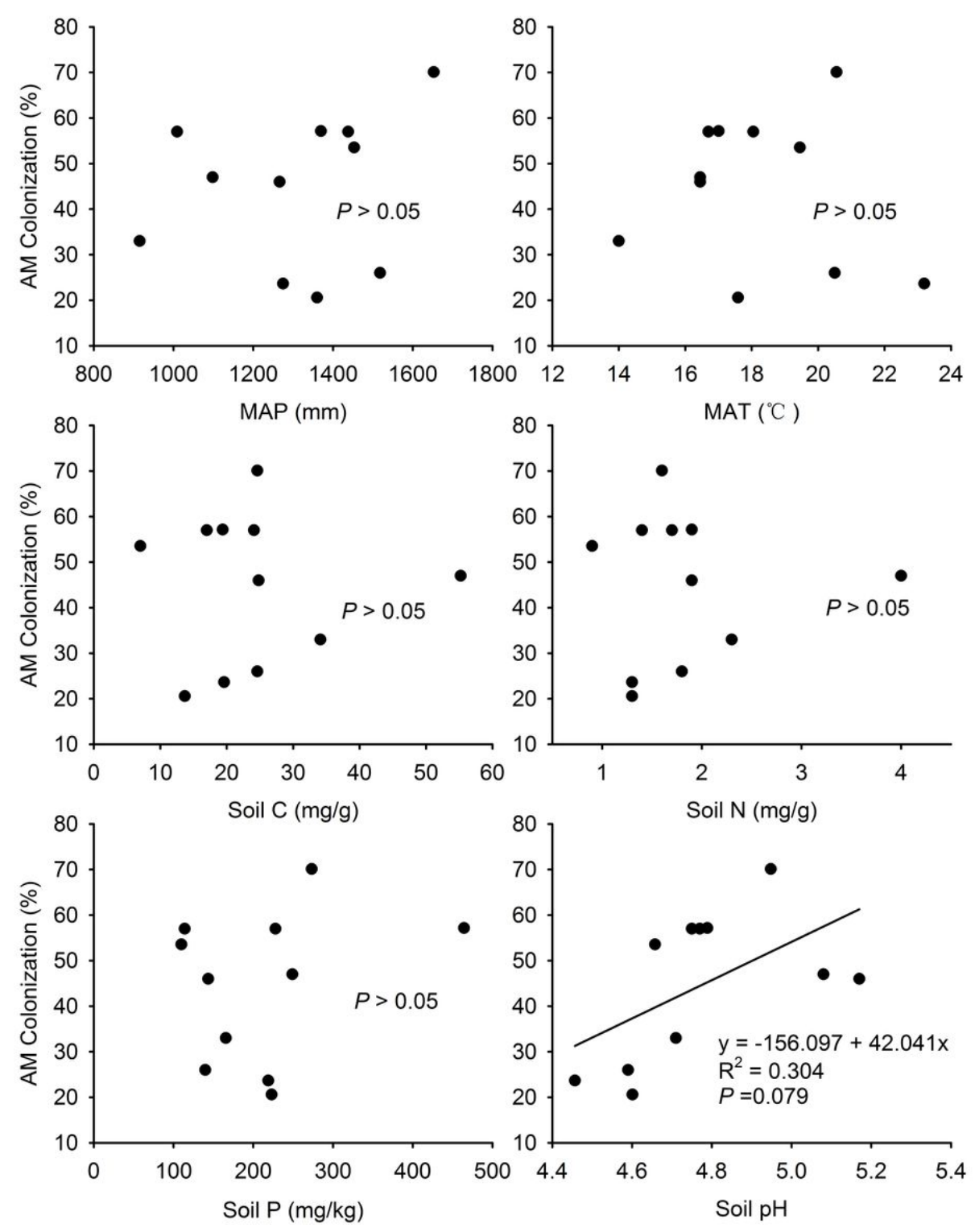

Figure 2

Linear regressions of $A M$ colonization and environmental factors $(N=11)$ (values are means of individual locations). 


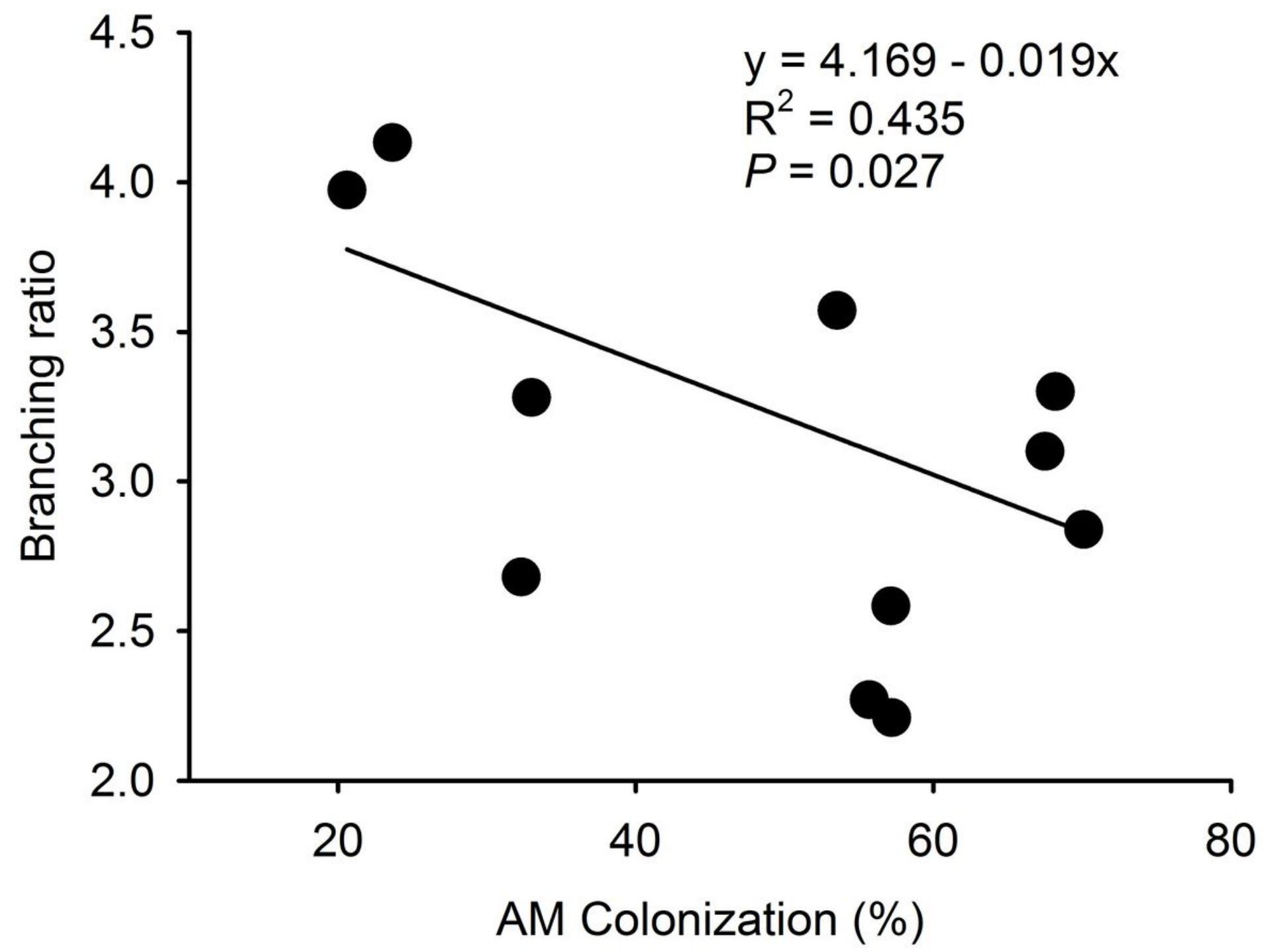

Figure 3

Linear regressions of branching ratio and AM colonization ( $N=11)$ (values are means of individual locations). 